\title{
ANALISIS SAMBUNGAN BAUT BALOK KOLOM RANGKA BAJA STRUKTURAL DENGAN PROFIL IWF MENGGUNAKAN PROGRAM BANTU ELEMEN HINGGA
}

\author{
Machmud Budi Sulistiyo ${ }^{* 1}$, Gati Annisa Hayu ${ }^{2}$ dan Entin Hidayah ${ }^{2}$ \\ 1 Mahasiswa, Program Studi S-1 Teknik Sipil, Universitas Jember \\ 2 Dosen, Jurusan Teknik Sipil, Universitas Jember \\ *Korespondensi: machmudbudi14@gmail.com
}

\begin{abstract}
Commonly joints problems (especially high strength bolt) were stiffness, ductility, and construction costs. This research was conducted with purpose to analyzed inner force and behavior that could be occurred on high strength bolted joints in steel frame using IWF profiles, such as stress, and reaction force-displacement. This study was divided into 2 step, first step was modeling on finite element software, and second step was analyzing the results and comparing it with the results from experimental study as validation base. In bolted joints model showed the best value on third trial with displacement value of 98,97 $\mathrm{mm}$ and reaction force of 41,57 KN. With validation to experimental results each one were 93,45\% and 94,05\%. Accuracy of hysteretic loop curve area was $98,46 \%$.
\end{abstract}

Keywords : displacement, finite element, hysteretic loop, joints, reaction force

\section{PENDAHULUAN}

Dewasa ini material bahan baja banyak digunakan dalam perencanaan dan pelaksanaan konstruksi, baik konstruksi gedung maupun jembatan. Konstruksi yang sering menggunakan bahan ini diantaranya sebagai apartemen atau hotel, perpustakaan, jembatan penyeberangan orang (JPO), jembatan rangka baja, maupun konstruksi sebagai fasilitas umum lainnya. Kemudahan dan keefektifan dalam operasional dan pelaksanaan di lapangan menjadi salah satu faktor banyaknya penggunaan material baja.

Elemen struktur utama dari bangunan rangka baja terdiri dari 3 elemen struktural utama, yaitu kolom, balok, dan sambungan antara keduanya [5]. Sambungan sangat penting diperhatikan karena perannya sebagai titik tumpu dari beban yang diterima gedung. Terdapat 3 macam sambungan pada konstruksi baja, yaitu: sambungan baut, sambungan las, dan sambungan paku keling. Namun yang sering digunakan di lapangan ialah 2 sambungan awal. Dua konsep utama telah muncul dalam menyediakan respon daktilitas yang tinggi dan kinerja yang andal : memperkuat sambungan dan atau memperlemah framing balok ke kolom, dengan tujuan menghindari kerusakan kolom [4].

Dalam penggunaan sambungan tersebut biasanya didukung oleh plat baja (end plate) ataupun juga tidak. Interaksi yang terjadi antara balok kolom seperti geometrik dan material dari bahan yang digunakan perlu di analisa pada saat beban layan. Hal ini dimaksudkan untuk mengetahui kekuatan dan kekakuan serta kegagalan yang terjadi pada sambungan diantaranya pergeseran, puntir, defleksi, dll.

Penelitian eksperimental statis maupun dinamis sudah sering dilakukan untuk mengetahui perilaku sebenarnya yang terjadi pada sambungan balok kolom baja, baik baut ataupun las. Permasalahan yang pada umumnya diangkat antara sambungan baut (khususnya baut mutu tinggi) ialah kekakuan, daktilitas, serta biaya konstruksi. Dari respon momen-rotasi sendi, kekakuan awal sendi adalah 4.4\% untuk Double Web Angles (DWA) dan 39\% untuk Top Seat Double web angles (TSD) dibandingkan dengan Full Welded (FW). 
Jika kriteria utama adalah rasio simpangan 3\%, momen yang didapat adalah 3.0, 24.1, dan 53.4 $\mathrm{kNm}$, masing-masing, untuk $D W A, T S D$, dan spesimen $F W$ [5].

Sedangkan penelitian ini bertujuan menganalisis gaya dalam serta perilaku yang mungkin terjadi pada sambungan baut mutu tinggi dan sambungan las pada portal baja dengan profil IWF menggunakan program bantu elemen hingga. Seperti tegangan dan kapasitas beban-perpindahan. Metode F.E memiliki ketepatan akurasi untuk parameter seperti sambungan dan metode F.E dapat mengurangi prosedur "trial and error" eksperimental dan juga mengurangi biaya yang relevan [1]. Hasil penelitian ini dibandingkan dengan penelitian eksperimental yang telah dilakukan sebelumnya.

\section{METODE PENELITIAN}

\subsection{Data Dasar Penelitian}

Seluruh material baja dalam penelitian ini yaitu profil kolom, profil balok, dan profil siku menggunakan baja standard (SS400) serta baut mutu tinggi dan detail pemodelan sambungan telah disesuaikan dengan data eksperimental dari penelitian Yang, dkk. (2007) yang berjudul "Cyclic Behavior of Bolted and
Welded Beam-to-Column Joints", berikut masing-masing spesifikasi tersebut :

- Elemen kolom menggunakan profil H-125 x 125 x 6.5 x 9

Elemen balok menggunakan profil $\mathrm{H}-250 \times 125 \times 6 \times 9$

Siku pada flange menggunakan profil L-75 × 75 × 6

- $\quad$ Siku pada web menggunakan profil L-50 x $50 \times 6$

Spesimen yang diteliti 1 buah sambungan baut semi kaku dengan keterangan TSD (top seat double web angles) atau sambungan antara sisi sayap balok dan kolom beserta antara sisi sayap balok dan web kolom.

Sesuai dengan penjelasan sebelumnya, seluruh komponen penyusun pemodelan portal balok kolom baja termasuk posisi/jarak setiap baut yang digunakan dalam penelitian ini disajikan dalam detail gambar profil penampang balok, kolom, dan sambungan seperti pada Gambar 1.

Baut yang digunakan merupakan baut mutu tinggi, tipe friksi, F10T dan berdiameter M12. Spesimen TSD menggunakan baut berjumlah 17 buah, 2 buah siku sayap, 2 buah siku badan, 1 profil kolom, dan 1 profil balok.

\section{Siku Badan \\ (L-50x50x6)}
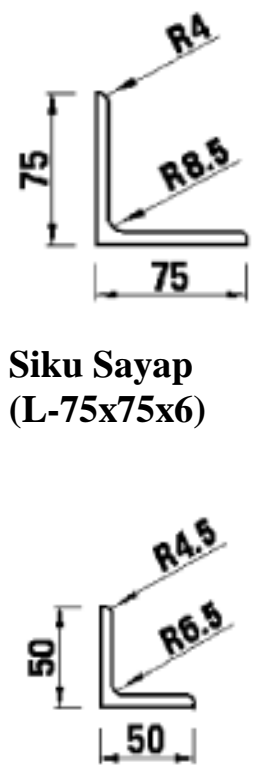
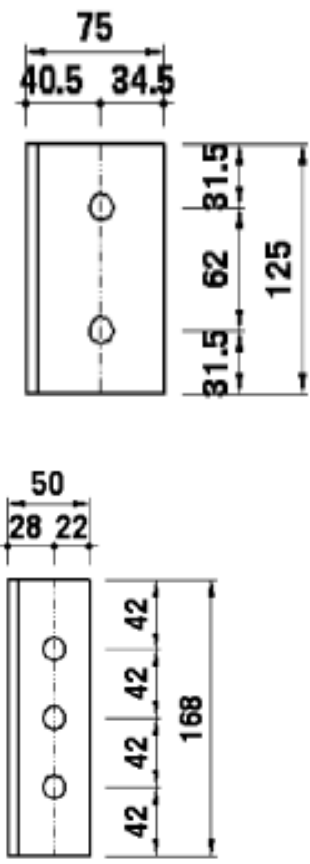

Kolom

(H-125x1256.5x9)

125

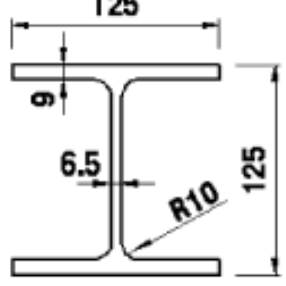

Balok

(H-250x125x6x9)

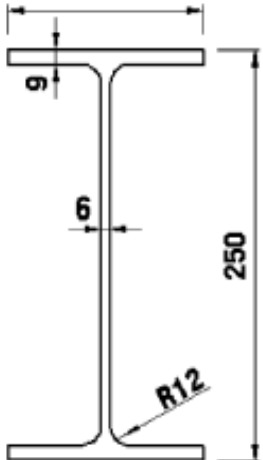

Gambar 1. Detail Elemen Penampang [5] 
Seluruh elemen penampang diatas diantaranya profil IWF balok kolom, dan profil sambungan siku L, yang digunakan dalam pemodelan memiliki karakteristik, sifat mekanis, dan mutu masing-masing sesuai dengan jenisnya, disajikan dalam Tabel 1, Tabel 2, dan Tabel 3.

Tabel 1. Detail Properti Penampang [5]

\begin{tabular}{|c|c|c|c|c|c|}
\hline \multicolumn{2}{|l|}{ Elemen } & Balok & Kolom & $\begin{array}{c}\text { Siku } \\
\text { Sayap }\end{array}$ & $\begin{array}{c}\text { Siku } \\
\text { Badan }\end{array}$ \\
\hline \multicolumn{2}{|l|}{$\begin{array}{l}\text { Luas } \\
\left(\mathrm{mm}^{2}\right)\end{array}$} & 3766 & 3031 & 873 & 564 \\
\hline \multicolumn{2}{|l|}{$\begin{array}{l}\text { Berat } \\
(\mathrm{N} / \mathrm{m})\end{array}$} & 296 & 238 & 68.5 & 44.3 \\
\hline \multirow{2}{*}{$\begin{array}{l}\text { Momen } \\
\text { inersia } \\
\left(\mathrm{x} 10^{4} \mathrm{~mm}^{4}\right)\end{array}$} & $\mathrm{I}_{\mathrm{x}}$ & 4050 & 847 & 46.1 & 12.6 \\
\hline & $\mathrm{I}_{\mathrm{y}}$ & 294 & 293 & 46.1 & 12.6 \\
\hline \multirow{2}{*}{$\begin{array}{l}\text { Jari-jari } \\
\text { girasi } \\
(\mathrm{mm})\end{array}$} & $r_{x}$ & 104 & 52.9 & 23 & 15 \\
\hline & $\mathrm{r}_{\mathrm{y}}$ & 27.9 & 31.1 & 23 & 15 \\
\hline \multirow{2}{*}{$\begin{array}{l}\text { Modulus } \\
\text { penampang } \\
\left(\mathrm{x} 10^{3} \mathrm{~mm}^{3}\right)\end{array}$} & $S_{x}$ & 324 & 136 & 1.48 & 3.55 \\
\hline & $\mathrm{S}_{\mathrm{y}}$ & 47 & 47 & 1.48 & 3.55 \\
\hline
\end{tabular}

Tabel 2. Geometri Profil Siku [5]

\begin{tabular}{lll}
\hline \multicolumn{1}{c}{ Parameter } & \multicolumn{1}{c}{ Siku Badan } & \multicolumn{1}{c}{ Siku Sayap } \\
\hline $\begin{array}{l}\text { Ukuran } \\
\text { penampang }\end{array}$ & L-50 x 50 x 6 & L-75 x 75 x 6 \\
\hline Panjang (mm) & 168 & 125 \\
\hline Ukuran (mm) & 28 & 40.5 \\
\hline Bubungan $(\mathrm{mm})$ & 42 & 63 \\
\hline
\end{tabular}

Pembebanan siklik yang digunakan sesuai dengan riwayat pembebanan pada jurnal eksperimental, dengan rincian seperti pada Tabel 4 dan Gambar 2. Tujuan dari pengujian ini adalah untuk menyajikan bukti bahwa sambungan balok kolom atau sambungan menuju kolom memenuhi persyaratan untuk kekuatan dan riwayat sudut simpangan atau sudut rotasi sambungan [2]. Perencanaan semua sambungan balok-ke-kolom yang digunakan pada Sistem Rangka Pemikul Beban Gempa harus didasarkan pada hasil-hasil pengujian kualifikasi yang menunjukkan rotasi inelastik sekurang-kurangnya 0,03 radian [3].

Tabel 4. Program Pembebanan [5]

\begin{tabular}{ccc}
\hline Tahap & $\begin{array}{c}\text { Perpindahan } \\
(\mathrm{mm})\end{array}$ & $\begin{array}{c}\text { Total Rotasi } \\
(\% \text { rad. })\end{array}$ \\
\hline 1 & \pm 3 & 0.32 \\
\hline 2 & \pm 6 & 0.64 \\
\hline 3 & \pm 9 & 0.96 \\
\hline$\cdots$ & $\cdots$ & $\cdots \cdots$ \\
\hline 6 & \pm 18 & 1.92 \\
\hline$\cdots$ & $\cdots \cdots$ & $\cdots \cdots$ \\
\hline$\cdots$ & $\cdots$ & $\cdots \cdots$ \\
\hline 9 & \pm 30 & 3.20 \\
\hline 10 & \pm 35 & 3.73 \\
\hline$\cdots$ & $\cdots$ & $\cdots \cdots$ \\
\hline 13 & \pm 50 & 5.33 \\
\hline 14 & \pm 60 & 6.40 \\
\hline$\cdots$ & $\cdots$ & $\cdots \cdots$ \\
\hline$\cdots$ & $\cdots$ & $\cdots \cdots$ \\
\hline 18 & \pm 100 & 10.67 \\
\hline
\end{tabular}

Tabel 3. Penampang Mekanis Baja [5]

\begin{tabular}{|c|c|c|c|c|c|c|}
\hline \multicolumn{2}{|c|}{ Elemen } & Kelas Baja & $\begin{array}{c}\text { Kuat Leleh } \\
(\mathrm{MPa})\end{array}$ & $\begin{array}{c}\text { Kuat Tarik } \\
\text { (MPa) }\end{array}$ & $\begin{array}{l}\text { Rasio } \\
\text { Hasil }\end{array}$ & $\begin{array}{c}\text { Perpanjangan } \\
(\%)\end{array}$ \\
\hline \multirow[t]{2}{*}{ Balok } & Sayap & \multirow[t]{10}{*}{ SS400 } & 328 & 447 & 0.73 & 31.25 \\
\hline & Badan & & 322 & 423 & 0.76 & 32.50 \\
\hline \multirow[t]{2}{*}{ Kolom } & Sayap & & 347 & 466 & 0.74 & 27.50 \\
\hline & Badan & & 333 & 461 & 0.72 & 33.75 \\
\hline \multicolumn{2}{|c|}{ Siku sayap } & & 307 & 432 & 0.72 & 32.50 \\
\hline \multicolumn{2}{|c|}{ Siku badan } & & 350 & 471 & 0.74 & 28.75 \\
\hline \multirow{3}{*}{$\begin{array}{l}\text { Nilai } \\
\text { rata-rata }\end{array}$} & Sayap & & 338 & 457 & 0.74 & 29.38 \\
\hline & Badan & & 328 & 442 & 0.74 & 33.13 \\
\hline & Siku & & 329 & 452 & 0.73 & 30.94 \\
\hline \multicolumn{2}{|l|}{$\begin{array}{l}\text { Total } \\
\text { rata-rata }\end{array}$} & & 332 & 450 & 0.74 & 31.15 \\
\hline
\end{tabular}




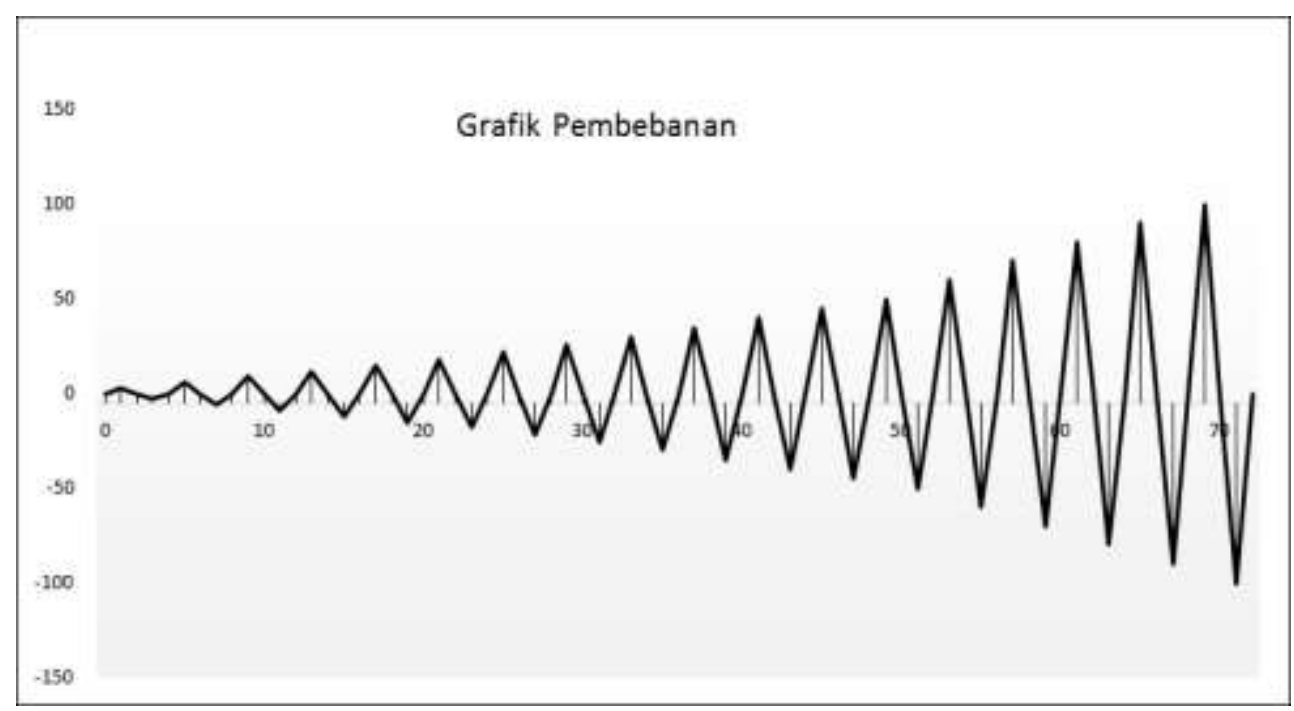

Gambar 2. Grafik Pembebanan Siklik

\subsection{Pemodelan Portal Balok Kolom Baja}

Pemodelan portal hanya satu sisi balok menuju kolom dimana diasumsikan sebagai sambungan momen balok kolom baja eksterior. Struktur balok diasumsikan sebagai kantilever, sedangkan struktur kolom dijepit pada kedua sisi ujung. Penelitian dilakukan dengan menghiraukan perilaku beban aksial pada kolom dan geser pada balok.

Pada Gambar 3 ditampilkan posisi pembebanan yang ditempatkan pada balok dengan jarak $1000 \mathrm{~mm}$ dari titik pusat kolom. Sementara dimensi kolom sepanjang $2200 \mathrm{~mm}$ dan balok sepanjang $1200 \mathrm{~mm}$.

Gambar 4 merupakan tampilan sambungan portal baut dan las dalam visualisasi 3 dimensi. Sedangkan detail sambungan baut ditampilkan pada Gambar 5.

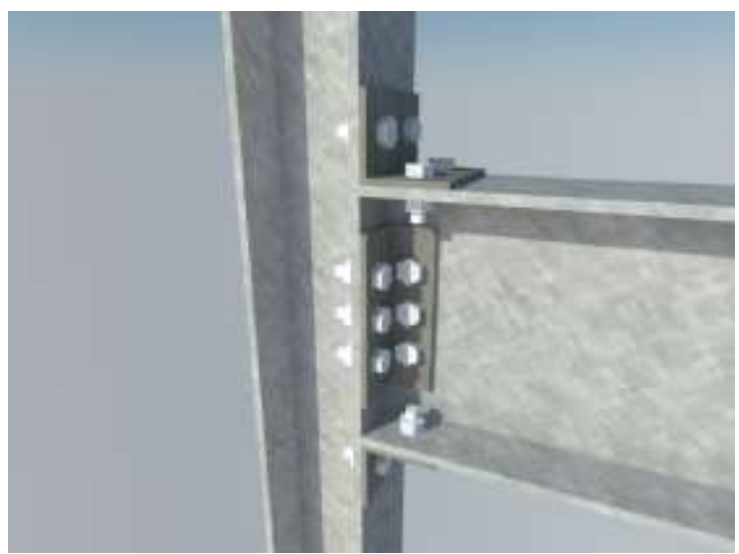

Gambar 4. Pemodelan Sambungan



Gambar 3. Portal Balok Kolom Baja


Gambar 5. Detail Sambungan 


\section{PEMBAHASAN}

\subsection{Hasil Perbandingan}

Grafik analisis kapasitas

beban-perpindahan dibandingkan dengan hasil eksperimental untuk memastikan validitas dari pemodelan yang dibuat. Dalam grafik yang dihasilkan terlihat hubungan yang tidak berbeda jauh antara hasil analisis FEM dengan eksperimental. Untuk selanjutnya, grafik berwarna oranye menunjukkan hasil analisis eksperimental dan grafik berwarna biru menunjukkan hasil analisis FEM.

Hal ini menunjukkan bahwa teknik uji material yang biasa dilakukan di laboratorium atau eksperimental, mampu diaplikasikan dengan baik oleh program bantu elemen hingga ini. Namun dengan beberapa kondisi, ada beberapa hal yang tidak bisa dianalisis secara sepihak oleh program bantu ini. Dalam kasus ini, contohnya data material grafik tegangan regangan mutu baja yang dibutuhkan dalam input data sebelum analisis dilakukan. Nilai ini tidak bisa didapatkan dalam analisis program bantu ini, atau membutuhkan hasil eksperimental yang telah dilakukan pada penelitian sebelumnya.

Bentuk grafik sambungan baut memiliki karakteristik perilaku grafik hysteresis terjepit, puncak deformasi yang selip, lalu kemudian kaku. Setelah melewati batas elatis dan leleh, kondisi material telah mencapai plastis, deformasi yang terjadi tidak bisa kembali seperti semula. Pada kondisi tersebut proses pembebanan peregangan dapat menghasilkan grafik hystereric loop, dimana energi dari material hilang dan disebut sebagai energi disipasi dengan satuan luasan dari grafik tersebut.

\subsubsection{Analisis Percobaan 1}

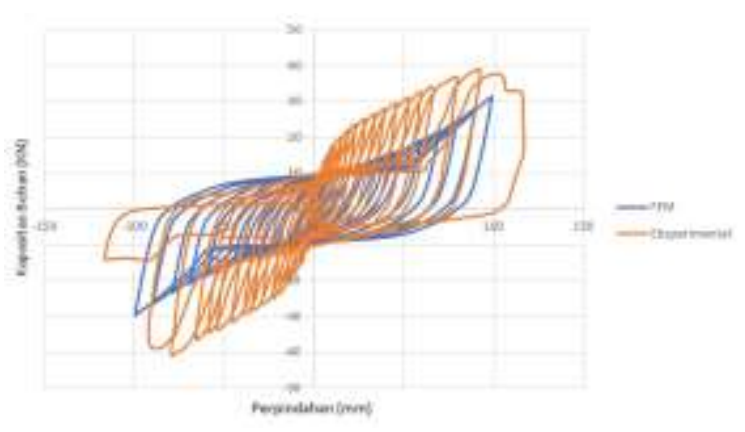

Gambar 6. Grafik Perbandingan Sambungan Baut Percobaan 1
Grafik sambungan baut eksperimental menunjukkan nilai kapasitas beban yang turun setelah menyentuh nilai $39,1 \mathrm{KN}$ dengan perpindahan sebesar $92,5 \mathrm{~mm}$. Selain itu juga menunjukkan nilai kapasitas beban yang menurun pada tahap akhir pembebanan meskipun perpindahan tetap meningkat.

Grafik FEM pada gambar 6 dihasilkan dari total increment sebanyak 1138 step. Pada percobaan ini dihasilkan leleh pertama balok pada beban sebesar $\pm 9,48$ KN dan titik displacement sekitar $\pm 8,63 \mathrm{~mm}$. Leleh ini terjadi pada pembebanan step ke-36. Nilai terus meningkat sampai mecnapai nilai maksimum perpindahan sebesar 99,09 $\mathrm{mm}$ dengan kapasitas beban 31,31 KN.

Selip setelah titik puncak deformasi pada percobaan 1 sambungan baut menunjukkan terjadinya gap terbuka antara siku sayap dengan sayap kolom pada pembebanan tekan. Setelah itu gap tertutup atau kembali bersentuhan lagi antara siku sayap dengan sayap kolom pada pembebanan tarik. Pemodelan pertama menunjukkan hasil yang paling berbeda dengan hasil eksperimental. Hal ini disebabkan oleh perilaku balok yang terlalu kaku, akibat pemberian interaksi tie constraint pada kepala baut dan mur.

\subsubsection{Analisis Percobaan 2}



Gambar 7. Grafik Perbandingan Sambungan Baut Percobaan 2

Percobaan kedua pada Gambar 7, grafik dihasilkan dari 1296 increment. Pada pembebanan tahap ke-32 pemodelan pada percobaan kedua menunjukkan leleh pertamanya setelah beban mencapai $\pm 19,89 \mathrm{KN}$ dan nilai displacement sebesar $\pm 8,93 \mathrm{~mm}$. Nilai perpindahan - kapasitas beban maksimum berturut-turut $99,73 \mathrm{~mm}$ dan $46,74 \mathrm{KN}$.

Grafik percobaan kedua menunjukkan perilaku yang masih terlalu kaku terlihat dari deformasi yang mampu menahan beban lebih besar daripada grafik eksperimental. Hal ini 
disebabkan perilaku tie constraint pada kepala baut dan mur dengan siku sayap.

\subsubsection{Analisis Percobaan 3}



Gambar 8. Grafik Perbandingan Sambungan Baut Percobaan 3

Grafik pada Gambar 8 didapatkan hasil analisis sebanyak 1395 increment. Berdasarkan grafik diatas, balok mengalami deformasi atau leleh pertama pada pembebenan ke-43 ketika mencapai beban $\pm 17,24 \mathrm{KN}$ dan nilai displacement sekitar $\pm 7,94 \mathrm{~mm}$. Nilai maksimum dari perpindahan dan kapasitas beban masing-masing 98,98 mm dan 41,57 KN.

Ketika baut diberikan algoritma interaksi surface-to-surface yang memungkinkan adanya pergeseran antara badan baut dengan lubang baut pada percobaan 2 dan percobaan 3 , grafik menunjukkan selip setelah gap terjadi ialah adanya hubungan antara badan baut dengan lubang baut yang menyebabkan leleh dan perpanjangan pada lubang baut. Percobaan sambungan baut ketiga merupakan hasil yang terbaik untuk mendekati hasil eksperimental, baik dari parameter nilai kapasitas beban-perpindahan maksimum maupun kemiripan grafik yang dihasilkan.

Pada seluruh percobaan ketika leleh pertama terjadi, pada siku sayap muncul garis plastis pertama. Garis plastis tersebut terletak di garis lurus baut yang menempel pada sisi sayap kolom.

Grafik sedikit berbeda pada tahap akhir pembebanan, ini dikarenakan input tegangan pada Abaqus tidak melampirkan tegangan ultimit atau baja terus berdeformasi dalam kondisi perfectly plastic. Sehingga analisis tidak menunjukkan perilaku fatik atau kondisi ultimit pada balok.

Selain kondisi ultimit tersebut, beberapa faktor yang kemungkinan mempengaruhi perbedaan hasil analisis grafik FEM dengan eksperimental diantaranya :

1. Sifat mekanis material yang tidak sepenuhnya aktual, kelas baja SS400 pada balok, kolom, dan sambungan, kelas baut F10T pada baut.

2. Nilai koefisien friksi pada gesekan yang terjadi antar elemen.

3. Beban pre-tension tidak ditetapkan pada elemen baut juga memberikan efek pada kemampuan sambungan untuk merespon.

\subsection{Rekapitulasi Hasil Analisis}

Seluruh nilai yang didapatkan dari hasil analisis elemen hingga ditampilkan pada Tabel 5, selanjutnya dengan tambahan hasil dari analisis eksperimental pada setiap parameter.

Tabel 5. Rekapitulasi Hasil Analisis

\begin{tabular}{|c|c|c|c|c|c|c|c|}
\hline \multirow{2}{*}{\multicolumn{2}{|c|}{ Tipe Sambungan }} & \multirow{2}{*}{\multicolumn{2}{|c|}{$\begin{array}{c}\text { Kapasitas } \\
\text { Beban }(\mathrm{KN})\end{array}$}} & \multirow{3}{*}{$\begin{array}{c}\text { Validasi } \\
(\%)\end{array}$} & \multirow{2}{*}{\multicolumn{2}{|c|}{$\begin{array}{l}\text { Perpindahan } \\
\quad(\mathrm{mm})\end{array}$}} & \multirow{3}{*}{$\begin{array}{c}\text { Validas } \\
(\%)\end{array}$} \\
\hline & & & & & & & \\
\hline & & FEM & Eks. & & FEM & Eks. & \\
\hline \multirow{3}{*}{$\begin{array}{l}\text { Sambungan } \\
\text { Baut }\end{array}$} & Percobaan 1 & 31,31 & \multirow{3}{*}{39,1} & 80,07 & 99,09 & \multirow{3}{*}{92,5} & 93,35 \\
\hline & Percobaan 2 & 46,74 & & 83,66 & 99,73 & & 92,75 \\
\hline & Percobaan 3 & 41,57 & & 94,05 & 98,98 & & 93,45 \\
\hline
\end{tabular}




\subsection{Deformasi Eksperimental dengan \\ Pemodelan FEM \\ Gambar 9 dan Gambar 10 merupakan} deformasi yang terjadi pada sambungan baut pemodelan FEM dengan percobaan eksperimental. Kondisi plastis elemen ketika terjadi leleh hampir menyamai hasil percobaan eksperimental.



Gambar 9. Deformasi Sambungan Baut Eksperimental (Sumber: Yang, C.M., Cyclic behavior of bolted and welded beam-to-column joints)

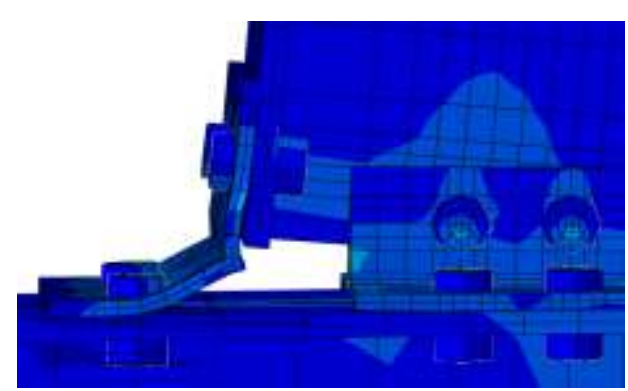

Gambar 10. Deformasi Sambungan Baut FEM

\subsection{Validasi Pemodelan}

Kelebihan dari program bantu ini ialah hasil analisis mampu ditampilkan pada setiap nodal yang telah ditetapkan pada pemodelan, dalam hal ini contohnya adalah tegangan. Peneliti dapat mengetahui nilai-nilai seperti tegangan normal, tegangan geser, pada setiap nodal di seluruh pemodelan. Penyebaran tegangan juga dapat di visualisasikan secara 3D dengan spektrum warna yang tertera. Selain itu, prosedur pembebanan atau jalannya pembebanan dari awal sampai selesai dapat divisualisasikan secara animatif.

Sesuai hasil percobaan dengan hasil terbaik, maka validasi untuk membuktikan bahwa pemodelan sesuai dengan keadaan eksperimental perlu dilakukan sebagai dasar penelitian bisa dianggap akurat. Pada penelitian ini menggunakan validasi berupa luasan hysteresis loop, nilai perpindahan dan kapasitas beban maksimum, serta perbandingan grafik dengan hasil eksperimental. Penentuan luasan hysteresis loop menggunakan program bantu OriginLab pada kedua sambungan.

Luasan dibuat pada program bantu dari titik awal grafik sampai titik terakhir grafik hysteretic loop, diantaranya step increment 1 1395. Grafik hysteresis loop eksperimental menunjukkan luasan sebesar 22534,14 KNmm sedangkan grafik hasil FEM pada Gambar 11 menunjukkan nilai sebesar 22886,29 $\mathrm{KNmm}$ dengan hasil ini maka tingkat keakuratan yang dihasilkan sebesar $98,46 \%$.
1

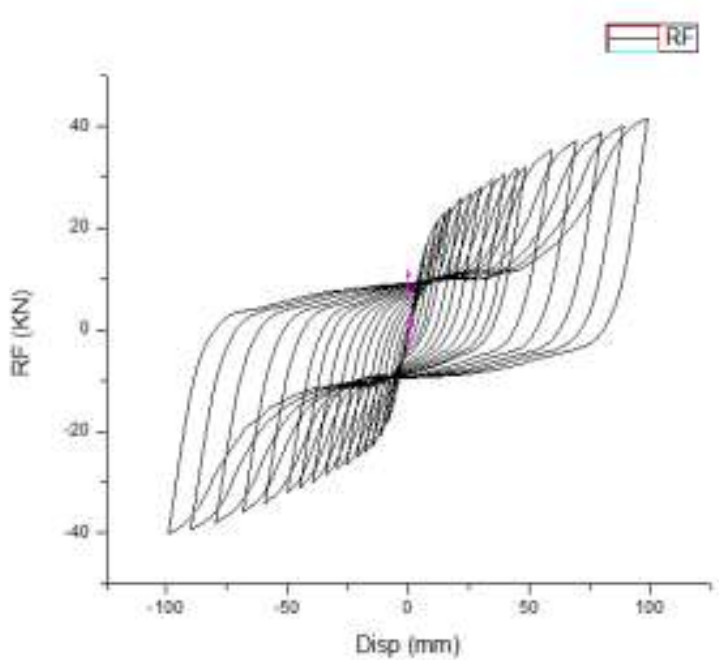

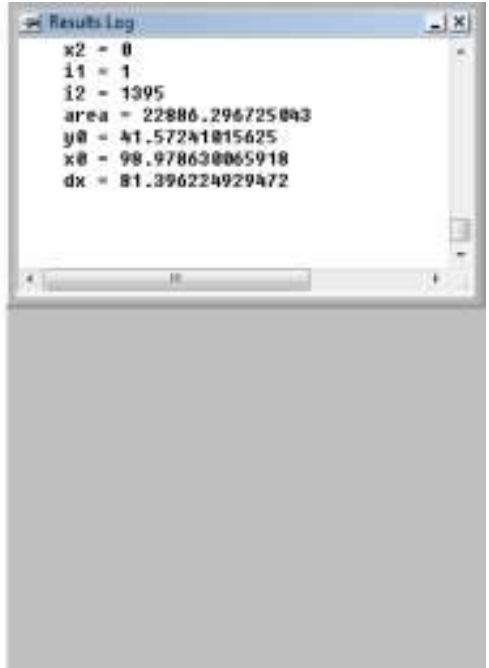

Gambar 11. Analisis OriginLab Sambungan Baut 


\section{KESIMPULAN DAN SARAN}

\subsection{Kesimpulan}

Berdasarkan penelitian dengan memodelkan sambungan baja menggunakan metode elemen hingga, dapat disimpulkan sebagai berikut :

1. Sesuai dengan analisis sambungan baut, hasil terbaik terdapat pada percobaan 3. Dengan tahapan pemodelan :

a. Seluruh bagian sejumlah 9 buah dibuat pada part module dengan solid element.

b. Data material yang digunakan pada property module diantaranya, mass density $\left(7,86 \times 10^{-9}\right.$ ton $\left./ \mathrm{mm}^{3}\right)$, elastic behaviors (Young's Modulus $=210000$ $M P a$, Poisson's Ratio = 0,3), dan plastic behaviors (Yield stress, Plastic strain).

c. Menggunakan Static, General pada step module sebagai prosedur pembebanan. Dengan pilihan output request tegangan ( $S$, stress components and invariants), regangan (PE, Plastic strain components dan PEEQ, Equivalent plastic strain), perpindahan (UT, Translations), serta beban (RT, Reaction forces).

d. Sayap dengan badan kolom dan sayap dengan badan balok di-merge. Interaksi yang digunakan merupakan surface-to-surface algorithm dengan spesifikasi satu permukaan sebagai master surface dan permukaan lainnya sebagai slave surface. Ditambahkan opsi small sliding, koefisien friksi sebesar 0,3 dan hard contact serta penalty.

e. Boundary condition pada beban menggunakan displacement/rotation, sedangkan untuk sisi bawah dan atas kolom menggunakan algoritma encastree. Pembebanan siklik diletakkan pada sumbu U2 dengan tabular data sebanyak 73 step.

f. Algoritma mesh menggunakan C3D8R dengan tipe hex, global seeds pada balok kolom sebesar $100 \mathrm{~mm}$ dan pada baut, siku, serta mur sebesar $10 \mathrm{~mm}$.

2. Hasil terbaik didapatkan untuk sambungan baut merupakan percobaan ketiga. Dengan analisis Abaqus menunjukkan kecenderungan nilai lebih besar daripada nilai analisis eksperimental, serta keakuratan nilai, diantaranya :

a. Sambungan baut memiliki nilai perpindahan dan kapasitas beban masing-masing sebesar $93,45 \%$ dan $94,05 \%$.

b. Validasi area hysteresis loop pada percobaan terbaik didapatkan untuk sambungan baut sebesar 98,46\% .

\subsection{Saran}

Berdasarkan kepada pengalaman peneliti selama melakukan penelitian terdapat beberapa saran yang bisa digunakan sebagai acuan penelitian selanjutnya, diantaranya :

1. Sebaiknya menggunakan data hasil eksperimental yang dapat ditinjau langsung atau memastikan data sesuai dengan parameter yang ingin dicari, dengan harapan data sekunder yang dibutuhkan mampu didapatkan secara mudah.

2. Memastikan terlebih dahulu parameter yang diinginkan mampu dihasilkan melalui program bantu elemen hingga, melalui jurnal-jurnal penelitian sebelumnya.

3. Hasil dari penelitian ini dapat dijadikan acuan untuk penelitian lebih lanjut dengan mencari nilai momen-rotasi dari pemodelan sambungan baut dan las balok kolom yang sama.

\section{DAFTAR PUSTAKA}

[1] Abdollahzadeh, G., dan S.M. Shabanian, Analytical and Experimental Studies on Behavior of Beam to Column Connections with Flange Plate under Monotonic Loading, 4(3), 2013: 208-211

[2] American Institute of Steel Construction, Seismic Provisions for Structural Steel Buildings, 341-16, Chicago, 2016: 142

[3] Departemen Pekerjaan Umum, Tata Cara Perencanaan Struktur Baja untuk Bangunan Gedung, SNI 03 - 1729 - 2002, 2002: 129

[4] Sofias, C.E., C.N. Kalfas, dan D.T. Pachuomis, Experimental and FEM Analysis of Reduced Beam Section Moment Endplate Connections Under Cyclic Loading, 59, 2014: 320-329

[5] Yang, C.M., dan Y.M. Kim, Cyclic Behavior of Bolted and Welded Beam-to-Column Joints, 49, 2007: 635-649 